\title{
Effect of testosterone on lipolysis in human pre-adipocytes from different fat depots
}

\author{
A. Dicker ${ }^{1}$ M. Rydén ${ }^{1}$ E. Näslund ${ }^{3}$ I. E. Muehlen ${ }^{1} \cdot$ M. Wirén ${ }^{2} \cdot$ M. Lafontan ${ }^{4}$ P. Arner ${ }^{1}$ \\ ${ }^{1}$ Department of Medicine, M61, Huddinge University Hospital, Karolinska Institute, Stockholm, Sweden \\ 2 Department of Surgery, Huddinge University Hospital, Karolinska Institute, Stockholm, Sweden \\ ${ }^{3}$ Department of Surgery, Danderyd Hospital, Stockholm, Sweden \\ ${ }^{4}$ INSERM, French National Institute for Health and Medical Research, Toulouse, France
}

\section{Abstract}

Aim/hypothesis. Regional differences in lipolysis, with higher lipolytic activity in visceral than subcutaneous fat, are important for the development of insulin resistance and might be influenced by testosterone.

Methods. We studied testosterone-regulated lipolysis and protein expression (by western blot) in fully differentiated pre-adipocytes from visceral (omental) and abdominal subcutaneous adipose tissue from $52 \mathrm{hu}$ man subjects. These cells were isolated and cultured in a serum-free medium.

Results. Testosterone caused a specific, time- and concentration-dependent $50 \%$ reduction of catecholamine-stimulated lipolysis in the subcutaneous depot. Half of the maximum effect occurred at $10 \mathrm{nmol} / \mathrm{l}$. The inhibitory effect was due to the inability of $\beta$ adrenoceptors and cyclic AMP to stimulate the protein kinase A, hormone-sensitive lipase complex. Testosterone caused a depot-specific 50\% reduction of the protein expression of hormone-sensitive lipase and $\beta_{2}$-adrenoceptors in differentiated subcutaneous pre- adipocytes, but no change in $\beta_{1}$-adrenoceptors, protein kinase A subunits or perilipin expression. In contrast, testosterone had no effect on lipolysis or protein expression in the visceral depot. However, testosterone receptors were present in both depots, and the hormone inhibited adipocyte leptin secretion. Similar effects on lipolysis were observed with dihydrotestosterone.

Conclusions/interpretation. Testosterone in physiological concentrations causes a depot-specific reduction of catecholamine-stimulated lipolysis in subcutaneous fat cells, probably due to reduced protein expression of $\beta_{2}$-adrenoceptors and hormone-sensitive lipase. This could be an important pathogenic factor underlying regional differences in lipolysis and development of insulin resistance and hyperandrogenic polycystic ovary syndrome. [Diabetologia (2004) 47:420-428]

Keywords Adipose tissue - Cyclic AMP . Hormone-sensitive lipase · Lipolysis · Perilipin · Protein kinase A - Testosterone
Received: 13 August 2003 / Revised: 28 November 2003

Published online: 30 January 2004

C Springer-Verlag 2004

P. Arner (ष)

Department of Medicine, M61, Huddinge University Hospital, Karolinska Institute, 14186 Stockholm, Sweden

E-mail: peter.arner@medhs.ki.se

Abbreviations: PCOS, polycystic ovary syndrome . GPDH, glycerol-3-phosphate dehydrogenase $\cdot$ AR, adrenergic receptor - HSL, hormone-sensitive lipase - PKA, protein kinase A · OD, optical density · dcAMP, dibutyryl cyclic AMP
Adipose tissue plays an important pathophysiological role in several conditions featuring insulin resistance, e.g. upper-body obesity, glucose intolerance, insulin resistance, Type 2 diabetes, metabolic syndrome, dyslipidaemia and polycystic ovary syndrome (PCOS) [1, $2,3,4,5]$. Regional variations in adipose tissue function seem to have an additional bearing on insulin resistance, and visceral fat accumulation has a stronger association with insulin resistance than subcutaneous fat accumulation $[6,7,8,9,10]$. This has in part been attributed to higher lipolytic activity in visceral than in subcutaneous adipose tissue $[6,7,8,9,10]$. Catecholamines are the major lipolytic hormones in hu- 
mans and catecholamine-stimulated lipolysis is higher in visceral fat cells than in subcutaneous adipocytes $[6,7,8,9,10]$. Moreover, due to portal vein drainage, high lipolytic activity in visceral fat cells leads to increased "portal" fatty acids which in turn alter liver function $[6,7,8,9,10]$. It is possible that liver dysfunction at least in part causes the glucose intolerance, hyperinsulinaemia and dyslipidaemia often observed in conditions characterised by insulin resistance.

The mechanisms behind the higher rate of catecholamine-induced lipolysis seen in visceral fat cells than in subcutaneous adipocytes are unknown. These regional variations in lipolysis are much more apparent in obese men than in obese women $[11,12]$. In PCOS, which is a hyperandrogenic state [2], catecholamineinduced lipolysis is decreased in subcutaneous fat cells, but increased in visceral adipocytes [13, 14]. Finally, upper-body obesity is more common among men than among women $[6,7,8,9,10]$. Thus sex differences in lipolysis and the findings for PCOS suggest that testosterone could be involved in the regional differences in lipolysis.

We have recently developed a human in vitro model for mechanistic studies of regional differences in adipocyte lipolysis [15]. In this model pre-adipocytes from fibroblast-like cells from the stromal vascular compartment of subcutaneous abdominal and omental (visceral) adipose tissue are isolated and differentiated into fat cells under defined conditions in a serum-free environment. These cells maintain the lipolytic phenotype of adult mature fat cells i.e. a high catecholamine-induced rate of lipolysis in the omental region and a low rate in the subcutaneous region [15]. We investigated the importance of testosterone for lipolytic regulation in abdominal subcutaneous and omental pre-adipocytes differentiated in the above way.

\section{Subjects and methods}

Subjects. The study comprised 52 women and 8 men undergoing elective surgery because of obesity, abdominal hernia or gall stones. They were otherwise healthy. There was no selection on the basis of age or body weight. Body mass index varied between 28 and $72 \mathrm{~kg} / \mathrm{m}^{2}$. Age varied between 21 and 63 years. None of the subjects was on continuous medication. All subjects were operated in the morning, having fasted overnight. Only saline was given intravenously until adipose tissue was removed at the beginning of surgery. Subcutaneous adipose tissue was removed from the surgical incision and omental adipose tissue (5-10 g) was removed by laparoscopic procedures. The tissue was immediately brought to the laboratory for further processing. The study was carried out in accordance with the Declaration of Helsinki as revised in 2000. The hospital's ethics committee approved the study, which was explained in detail to each subject. All subjects gave informed consent.

Isolation and culture of adipocyte precursor cells. The isolation and differentiation of pre-adipocytes was done as described [16], with recent modifications [15]. Tissue fragments were incubated for $1 \mathrm{~h}$ at $37^{\circ} \mathrm{C}$ with $0.5 \mathrm{~g} / \mathrm{l}$ of collagenase (Sigma, St. Louis, Mo., USA) in Krebs Ringer Phosphate buffer ( $\mathrm{pH} 7.4$ ) containing $40 \mathrm{~g} / \mathrm{l}$ of dialysed BSA (fraction V, Sigma). The desegregated adipose tissue was filtered through a nylon mesh with a pore size of $250 \mu \mathrm{m}$ and the cell suspension was centrifuged for $10 \mathrm{~min}$ at $200 \mathrm{~g}$ at room temperature. The pellet was resuspended and incubated in $10 \mathrm{ml}$ erythrocyte lysis buffer consisting of $0.154 \mathrm{~mol} / \mathrm{l} \mathrm{NH}_{4} \mathrm{Cl}, 5.7 \mathrm{mmol} / \mathrm{l}$

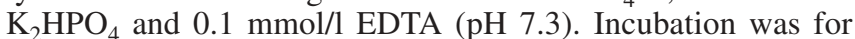
$10 \mathrm{~min}$ at room temperature. The pre-adipocyte fraction was centrifuged as above, resuspended in $10 \mathrm{ml}$ of DMEM/ NUT.MIX.F-12 medium (Gibco, Invitrogen, Sweden) and filtered through a cell strainer with a pore size of $70 \mu \mathrm{m}$. After an additional centrifugation step, the fraction was resuspended in DMEM/NUT.MIX.F-12 medium supplemented with $10 \%$ fetal calf serum and $100 \mu \mathrm{g} / \mathrm{ml}$ penicillin-streptomycin. Cells were inoculated into 24-well plates at a density of at least 150,000 cells $/ \mathrm{cm}^{3}(\mathrm{ml})$ and kept at $37^{\circ} \mathrm{C}$ in $5 \% \mathrm{CO}_{2}$ for not more than $20 \mathrm{~h}$. The cells were then washed and incubated until day 6 in serum-free medium, which consisted of DMEM/NUT.MIX.F-12 medium, $15 \mathrm{mmol} / \mathrm{l} \mathrm{HEPES,} 100 \mu \mathrm{g} / \mathrm{ml}$ penicillin-streptomycin, $2.5 \mu \mathrm{g} / \mathrm{ml}$ amphotericin B (Gibco Invitrogen), $100 \mathrm{nmol} / 1$ cortisol, $66 \mathrm{nmol} / 1$ insulin, $1 \mathrm{nmol} / 1$ triiodothyronine, $33 \mu \mathrm{mol} / \mathrm{l}$ biotin, $17 \mu \mathrm{mol} / \mathrm{l}$ patothenate, $10 \mu \mathrm{g} / \mathrm{ml}$ transferrin (Sigma) and $10 \mu \mathrm{mol} / \mathrm{l}$ rosiglitazone (BRL 49653) (kindly provided by SmithKline Beecham Pharmaceuticals, Harlow, Essex, UK). From day 6 testosterone (Sigma; $1 \mu \mathrm{mol} / \mathrm{l}$, unless otherwise stated) was added to the culture medium in 12 wells of a 24-well plate. The cells in the remaining wells served as control cells. In some experiments the testosterone receptor blocker flutamide (Sigma; $0.1 \mu \mathrm{mol} / \mathrm{l}$ ) was also added. In other experiments the specific testosterone dihydrotestosterone $(1 \mu \mathrm{mol} / \mathrm{l})$ was added instead of testosterone. On day 16 (unless otherwise stated) the experiment was ended and cells and medium analysed as described below. Proteins were extracted from cells in two or three wells using a protein lysis buffer containing $1 \%$ Triton $\mathrm{X}-100,50 \mathrm{mmol} / \mathrm{l}$ Tris- $\mathrm{HCl}(\mathrm{pH} \mathrm{7.6)}$, $150 \mathrm{mmol} / \mathrm{l} \mathrm{NaCl}$ and phenylmethylsulfonyl fluoride ( $1 \mathrm{mmol} / \mathrm{l})$, supplemented with protease inhibitors (Complete; Boehringer Mannheim, Indianapolis, Ind., USA). These total proteins were also used for western blot experiments.

Pre-adipocyte differentiation was assessed by quantifying glycerol-3-phosphate dehydrogenase (GPDH) activity, as described [16]. Cells from two or three wells were washed with PBS (pH 7.4) and harvested in pre-chilled $25 \mathrm{mmol} / \mathrm{l}$ Tris- $\mathrm{HCl}$ buffer containing $1 \mathrm{mmol} / \mathrm{l}$ EDTA ( $\mathrm{pH} \mathrm{7.4)}$ and $1 \mathrm{mmol} / \mathrm{l} 2-$ mercapto-ethanol. After sonication, aliquots of the cell extracts were added to an assay mixture containing $100 \mathrm{mmol} / \mathrm{l}$ triethanolamine- $\mathrm{HCl}$ buffer (pH 7.5), $2.5 \mathrm{mmol} / \mathrm{l}$ EDTA, $0.12 \mathrm{mmol} / \mathrm{l}$ NADH, and $0.1 \mathrm{mmol} / 1$ 2-mercapto-ethanol. Then GPDH activity was measured spectrophotometrically at $340 \mathrm{~nm}$. The reactions were started by adding $0.2 \mathrm{mmol} / \mathrm{l}$ dihydroxyacetone phosphate.

After exposure to testosterone or control medium, cells were subjected to lipolysis experiments as described [15]. In these experiments, cells were washed with DMEM/NUT.MIX.F-12 medium and then incubated in duplicate for $3 \mathrm{~h}$ with DMEM/NUT.MIX.F-12 medium containing 20 g/l BSA without or with the following: $10^{-4} \mathrm{~mol} / \mathrm{l}$ adrenaline (in the absence or presence of $10^{-4} \mathrm{~mol} / \mathrm{l}$ of the $\alpha_{2}$-adrenoceptor blocker yohimbine); $10^{-5} \mathrm{~mol} / \mathrm{l}$ of the non-selective $\beta$-adrenoceptor agonist isoprenaline; and $10^{-3} \mathrm{~mol} / \mathrm{l}$ of the phosphodiesterase-resistant cyclic AMP analog dibutyryl cyclic AMP (dcAMP). As the tissue available was often not sufficient to get cells to all wells in the 24-well plate, we were unable to use each lipolytic agent in the individual experiments. After incubation the medium was removed and kept at $-20^{\circ} \mathrm{C}$ for subsequent measurement of 
glycerol concentrations (an index of lipolysis) by bioluminescence [17]. Methodological experiments showed that during this period glycerol release was linear with time. Release of glycerol $(\mu \mathrm{mol} / \mathrm{l})$ was expressed as the concentration in the medium per GPDH activity. GPDH activity was expressed as $\mathrm{mU} / \mu \mathrm{g}$ of total protein.

Leptin in medium was measured as described [15]. In brief, $5 \mathrm{ml}$ medium was collected from control and testosteronetreated $(1 \mu \mathrm{mol} / \mathrm{l})$ cells, lyophilised and dissolved in $0.4 \mathrm{ml}$ of distilled water. An aliquot of $100 \mu \mathrm{l}$ was analysed according to the Quantikine Human Leptin Immunoassay kit protocol (R \& D Systems, Abington, UK). Results were corrected for the concentration factor and were expressed as secretion per $24 \mathrm{~h}$ in ng/l per GPDH activity.

Western blot experiments. Protein isolation and western blot analysis were done as described [14]. The protein extract from the cell experiments described above were frozen and kept at $-70^{\circ} \mathrm{C}$ until use. Because western blot experiments require at least $100 \mu \mathrm{g}$ for reliable results with the different antibodies and only small amounts of protein were recovered from individual experiments (usually less than $50 \mu \mathrm{g}$ from control or testosterone-treated cells), it was necessary to pool proteins from several subjects. The pooling was done as follows: four subjects were randomly picked for one subcutaneous and one omental pool. Protein $(30 \mu \mathrm{g}$; omental or subcutaneous) was taken from each individual sample into the pool, which had a total of $120 \mu \mathrm{g}$ of protein. Total protein $(100 \mu \mathrm{g})$ was loaded on $12 \%$ polyacrylamide gels and separated by standard SDSPAGE. Proteins were transferred on to a PVDF transfer membrane (Hybond-P, Amersham Pharmacia Biotech, Little Chalfont, UK). Blots were blocked for $1 \mathrm{~h}$ at room temperature in Tris-buffered saline with $0.1 \%$ Tween-20 and 5\% non-fat dried milk. This was followed by overnight incubation at $4{ }^{\circ} \mathrm{C}$ in the presence of primary antibodies directed against $\beta$-actin, $\beta_{1^{-}}$ and $\beta_{2}$-adrenergic receptors (AR), hormone-sensitive lipase (HSL) and against several different components of the protein kinase A (PKA) complex i.e. the catalytic subunit of PKA and the regulatory subunits of PKA I $\alpha$ and II $\beta$. In addition we used an antibody directed against both the regulatory subunits I $\alpha$ and II $\beta$. Primary antibodies against the PKA subunits were from Transduction Laboratories (Lexington, Ky., USA). The antibody against $\beta$-actin was from Sigma and those against $\beta_{1}$-AR or $\beta_{2}$-AR from Santa Cruz Biotechnology (Santa Cruz, Calif., USA). To confirm antibody specificity of the commercial antibodies, positive controls (recombinant protein or tissue extract) were included in all experiments as provided by the manufacturer. An antibody recognising HSL-long and HSLshort was generated in chicken as described [18]. In short, immunised chicken antiserum was affinity-purified against recombinant rat HSL coupled to a CNBr-activate Sepharose 4B column (Amersham Pharmacia Biotech, Uppsala, Sweden). The affinity-purified antibodies were shown to be specific for both forms of HSL. In five of the omental and subcutaneous protein extracts there was enough protein left for a separate western blot experiment to investigate testosterone receptor protein expression using an antibody from Santa Cruz Biotechnology. Secondary antibodies conjugated to horseradish peroxidase were from Sigma $(\alpha$-mouse 1:5000, $\alpha$-rabbit 1:2500, and $\alpha$-chicken 1:2500). Antigen-antibody complexes were detected by chemiluminescences using a kit of reagents from Pierce (Supersignal; Rockford, Ill., USA), and blots were exposed to high-performance chemiluminescence film (Amersham Pharmacia Biotech, Little Chalfont, UK). Films were scanned and the optical density (OD) of each band was analysed using the Image program (National Institute of Health, Bethesda, Md., USA) and expressed as OD $\mathrm{mm}^{-2}$
$100 \mu \mathrm{g}^{-1}$ of total protein. Methodological studies showed that the OD-reading for a specific protein was proportional to the amount of total protein $(50-150 \mu \mathrm{g})$ added to the gel.

Statistical methods. Values are means \pm SEM. All comparisons were made within subjects, i.e. control versus testosterone or subcutaneous versus omental. The western blot experiments were done in pooled extracts. However, the same subjects were included in the control and testosterone-treated sample, so these samples were also statistically considered as pairs. Student's paired $t$ test was used except when values appeared not to be normally distributed. Then Wilcoxon's paired signed rank test was used. When three or more samples from the same donor were compared (concentration-response and time-course experiments), ANOVA followed by Student's paired $t$ test was used. Statistical significance was accepted at a value of less than 0.05. Standard software packages were used for the calculations.

Drugs and chemicals. Adrenaline, BSA fraction V (lot no. A9418), dcAMP, glycerol kinase from Escherichia coli (G-4509), flutamide, isoprenaline, testosterone and yohimbine were obtained from Sigma. ATP monitoring reagent containing firefly luciferase came from BioThema (Stockholm, Sweden). All chemicals used were of the highest grade of purity that was commercially available.

\section{Results}

Adipocyte differentiation. In the subcutaneous region GPDH activity (mU/ $\mu \mathrm{g}$ protein) was $0.17 \pm 0.03$ in the absence and $0.14 \pm 0.03$ in the presence of testosterone. Corresponding values for the omental region were $0.13 \pm 0.02$ and $0.17 \pm 0.04$. There was no difference in GPDH activity between control and testosterone-treated cells in any region. However, to correct lipolysis for

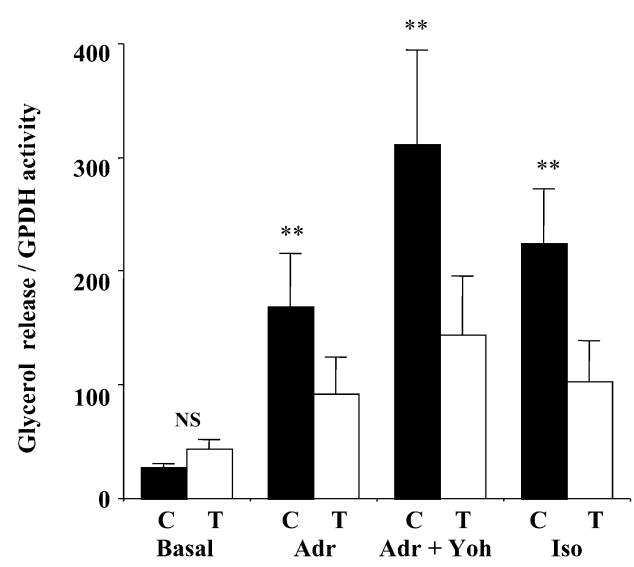

Fig. 1. Effect of testosterone treatment on lipolysis in subcutaneous pre-adipocytes. Basal lipolysis and lipolysis stimulated with $0.1 \mathrm{mmol} / 1$ adrenaline (Adr), adrenaline plus $0.1 \mathrm{mmol} / \mathrm{l}$ yohimbine (Yoh) and $10 \mu \mathrm{mol} / 1$ isoprenaline (Iso) were investigated. Differentiated pre-adipocytes had been incubated for 10 days without (filled bars) or with (open bars) $1 \mu \mathrm{mol} / 1$ testosterone. 26 subjects were investigated. Values are means \pm SEM and were subjected to paired comparison. $* * p \leq 0.01$. C, control; T, testosterone-treated; GPDH, glycerol-3-phosphate dehydrogenase 


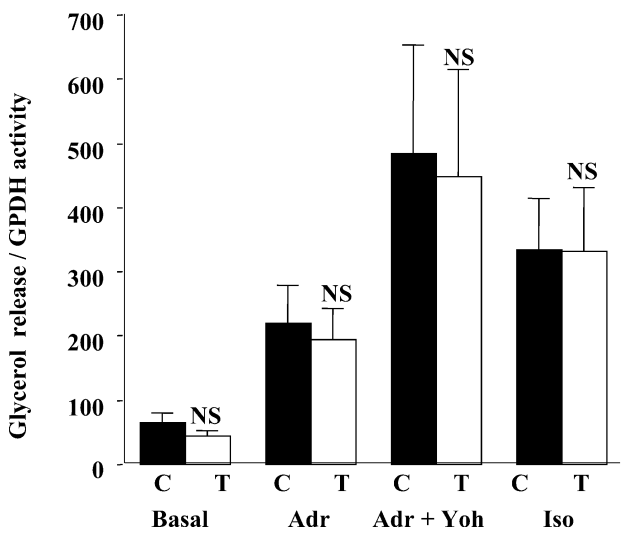

Fig. 2. Effect of $1 \mu \mathrm{mol} / 1$ testosterone treatment on lipolysis in omental pre-adipocytes. See legend to Fig. 1 for further details. C, control; T, testosterone-treated; GPDH, glycerol-3-phosphate dehydrogenase

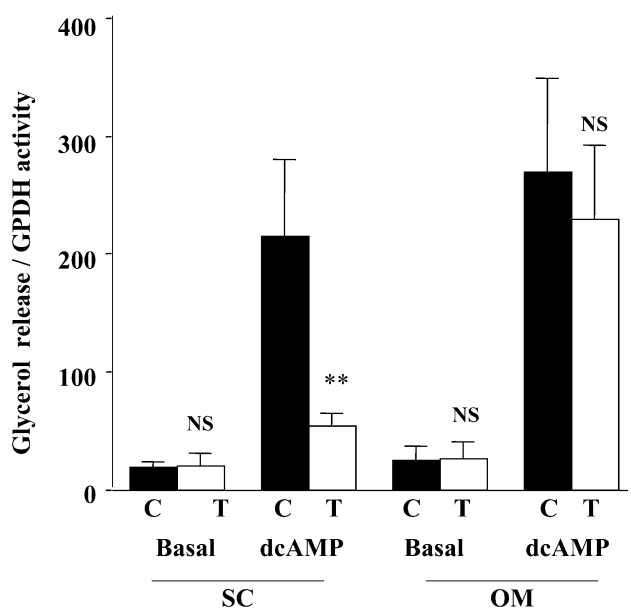

Fig. 3. Effect of $1 \mu \mathrm{mol} / \mathrm{l}$ testosterone treatment on basal and dibutyryl cyclic AMP (dcAMP)-stimulated lipolysis in subcutaneous (SC) or omental (OM) pre-adipocytes. Eight subjects were investigated. See legend to Fig. 1 for further details. C, control; T, testosterone-treated; GPDH, glycerol-3-phosphate dehydrogenase

small variations in cell loading and degree of differentiation, glycerol release was related to GPDH activity.

Lipolysis experiments. In the differentiated preadipocytes from the subcutaneous region (Fig. 1) testosterone $(1 \mu \mathrm{mol} / \mathrm{l})$ inhibited catecholamine-induced lipolysis by $50 \%$, irrespective of whether the cells were incubated with adrenaline alone or with adrenaline in combination with the $\alpha_{2}$-adrenergic blocking agent yohimibine or isoprenaline. Testosterone had no effect on basal lipolysis. More importantly, it had no effect on any lipolytic criterion in pre-adipocytes from the omental region (Fig. 2). In the absence or presence of testosterone and in both regions the addition of yohimbine improved the lipolytic effect of adrenaline,

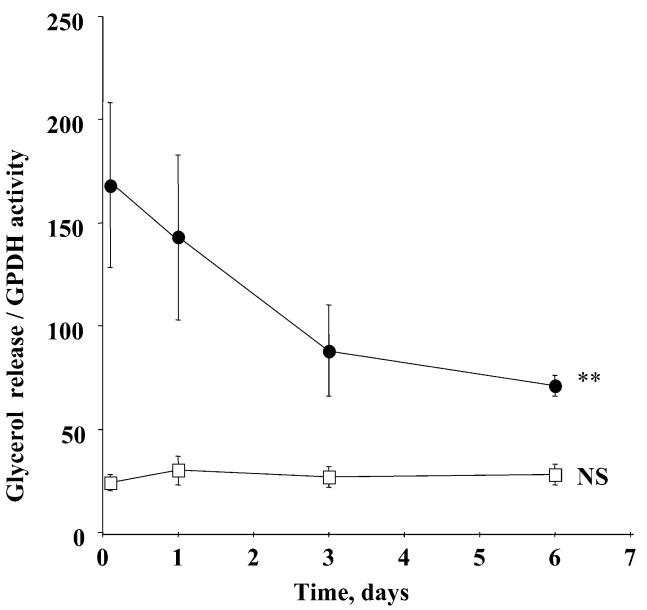

Fig. 4. Time-course for the effect of $1 \mu \mathrm{mol} / 1$ testosterone on basal (open squares) and adrenaline-induced $(0.1 \mathrm{mmol} / \mathrm{l})$ lipolysis (closed circles). Differentiated subcutaneous preadipocytes were exposed to testosterone for $0,1,3$ and 6 days. 11 subjects were investigated. All values were compared by ANOVA. The post hoc test showed that results for 3 and 6 days were significantly different from day 0 ( $p<0.05$ or better). See legend to Fig. 1 for further details. GPDH, glycerol-3phosphate dehydrogenase

showing an $\alpha_{2}$-adrenoceptor-mediated inhibitory effect on lipolysis $(p \leq 0.02)$.

In differentiated pre-adipocytes from both depots the phosphodiesterase-resistant cyclic AMP analogue dcAMP (Fig. 3) markedly stimulated the rate of lipolysis. In the subcutaneous region pretreatment with testosterone $(1 \mu \mathrm{mol} / \mathrm{l})$ reduced the lipolytic action of dcAMP by half, but the hormone had no effect in omental pre-adipocytes.

As testosterone was seen to have an effect on lipolysis in differentiated pre-adipocytes in the subcutaneous depot, we further characterised the lipolytic effect of testosterone only on subcutaneous cells. Addition of the hormone $(1 \mu \mathrm{mol} / \mathrm{l})$ caused a significant timedependent decrease of adrenaline-stimulated lipolysis (but not of basal lipolysis), an effect that was significant after three days $(p>0.01)$ and was maximal after 6 days (Fig. 4). The inhibitory effect on catecholamine-induced lipolysis was concentration-dependent $(p<0.01)$. Comparing all concentrations together, half of the maximum effect occurred at $10 \mathrm{nmol} / \mathrm{l}$ of testosterone $(p<0.05)$ and a maximal effect was obtained at $1 \mu \mathrm{mol} / \mathrm{l}$ (Fig. 5). Addition of $10^{-7} \mathrm{~mol} / \mathrm{l}$ of the antiandrogen flutamide counteracted significantly the reduction of lipolysis induced by $1 \mu \mathrm{mol} / \mathrm{l}$ of testosterone ( $p>0.01$, Fig. 6). Additional experiments showed that flutamide alone had no effect on lipolysis.

Although the objective of this study was not to directly compare lipolysis rates between pre-adipocytes in the omental and subcutaneous adipose depots, we investigated possible regional variations in lipolytic activity between omental and subcutaneous pre- 


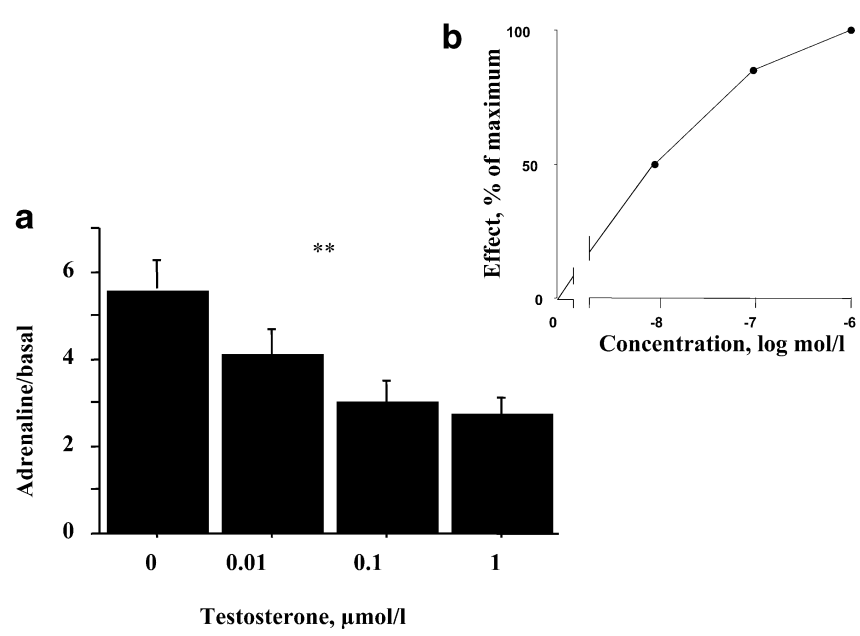

Fig. 5a, b. Effect of different concentrations of testosterone $(0$, $0.01,0.1,1 \mu \mathrm{mol} / \mathrm{l})$. The number of experiments was nine. To adjust for variation between experiments, values are expressed (a) as adrenaline divided by basal. They were compared by ANOVA. The post hoc test showed that a significant effect was obtained at $0.01 \mu \mathrm{mol} / \mathrm{l}(p<0.05)$. Data are also given as a concentration-response curve (b) in order to visualise the halfmaximum effect of testosterone. See legend to Fig. 1 for further details

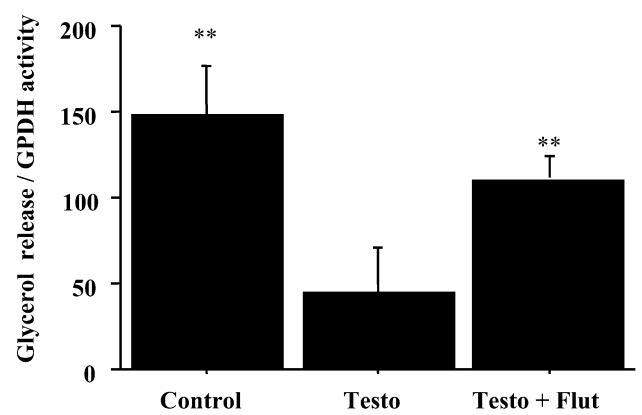

Fig. 6. Ability of $0.1 \mu \mathrm{mol} / \mathrm{l}$ flutamide to counteract the effect of $1 \mu \mathrm{mol} / 1$ testosterone on lipolysis in pre-adipocytes. Cells were incubated for 9 days with no addition (Control), with testosterone (Testo) or with testosterone + flutamide (Testo + Flut). They were subjected to lipolysis experiments with or without adrenaline. Values for adrenaline minus basal are depicted. Testo was compared with Control or Testo + Flut. See legend to Fig. 1 for further details. GPDH, glycerol-3-phosphate dehydrogenase

adipocytes that were differentiated without testosterone. We did this in 14 women, from whom we simultaneously investigated omental and subcutaneous preadipocytes that were cultured without testosterone. Basal glycerol release $\left(\mu \mathrm{mol} \cdot \mathrm{l}^{-1} \cdot \mathrm{mU}\right.$ GPDH $\cdot \mu \mathrm{g}^{-1}$ of protein) was similar in the two depots, i.e. $32 \pm 6$ for the subcutaneous and $36 \pm 8$ for the omental region. However, adrenaline-induced lipolysis was three times more rapid $(p<0.01)$ in the omental region $(482 \pm 224)$ than in the subcutaneous depot $(158 \pm 48)$.

Regulatory proteins. With regard to testosterone-induced changes in protein expression which were anal-
Table 1. Protein amounts in subcutaneous differentiated preadipocytes

\begin{tabular}{lrrl}
\hline Protein & Control & Testosterone & $\begin{array}{l}p \\
\text { value }\end{array}$ \\
\hline$\beta_{1}$-adrenoceptor & $5477 \pm 769$ & $5271 \pm 820$ & $\mathrm{NS}$ \\
$\beta_{2}$-adrenoceptor & $763 \pm 199$ & $326 \pm 141$ & 0.04 \\
PKAreg I- $\alpha$ & $1019 \pm 679$ & $820 \pm 199$ & $\mathrm{NS}$ \\
PKAreg II- $\beta$ & $1501 \pm 354$ & $1551 \pm 381$ & $\mathrm{NS}$ \\
PKA Cat & $2600 \pm 615$ & $2224 \pm 630$ & $\mathrm{NS}$ \\
Hormone-sensitive lipase & $2809 \pm 353$ & $1579 \pm 399$ & 0.02 \\
Perilipin & $3261 \pm 476$ & $3354 \pm 487$ & $\mathrm{NS}$ \\
Actin & $3424 \pm 313$ & $3336 \pm 290$ & $\mathrm{NS}$ \\
\hline
\end{tabular}

Values are means \pm SEM of 10 experiments $\left(\mathrm{OD} \cdot \mathrm{mm}^{-2}\right.$. $100 \mu^{-1}$ total protein). They were compared by Wilcoxon's signed rank test. All individual protein values were corrected for actin values and actin as control protein was set to $100 \%$. OD, optical density; PKAreg I- $\alpha$, PKAreg II- $\beta$, protein kinase A-regulatory subunits $\alpha$ and $\beta$; PKA Cat, protein kinase A-catalytic subunit

ysed by western blot, we found (Table 1) that protein concentrations of $\beta$-actin were not influenced by testosterone. However, to correct for minor variations in protein loading, each protein sample was corrected for $\beta$-actin expression and the results were expressed in relative units. The protein concentrations of HSL and $\beta_{2}$-AR were decreased by almost $50 \%$ in the testosterone-treated cells. The effect was specific as the hormone had no effect on the expression of several other proteins measured in the same cells. The same western blot experiments were done on omental cells. No effect of testosterone was observed on any protein.

Specificity of testosterone results. The specificity of the observed results for testosterone was further analysed (Fig. 7) by investigating testosterone receptor expression in five omental and five subcutaneous protein extracts. All omental and subcutaneous samples had a clear presence of testosterone receptors and there was no apparent depot difference in protein expression. In 25 subjects we compared leptin secretion. In omental and in subcutaneous cells a significant $(p<0.01)$ reduction (almost $45 \%$ ) of leptin release was induced with testosterone $(1 \mu \mathrm{mol} / \mathrm{l})$. Finally, the highly selective testosterone receptor agonist dihydrotestosterone was found in eight subjects to reduce adrenaline-induced lipolysis by about $50 \% \quad(p<0.05)$ in subcutaneous cells. It did not influence adrenaline-induced lipolysis in omental cells.

Studies of subgroups. This investigation was predominantly done on women and there was a large variation in BMI. The number of subjects included in the experiments dealt with by Figs. 1 and 2 was large enough for subpopulation analysis, in which 23 women and 3 men were included. Omission of the men from analysis had no important effect on the results. We also 


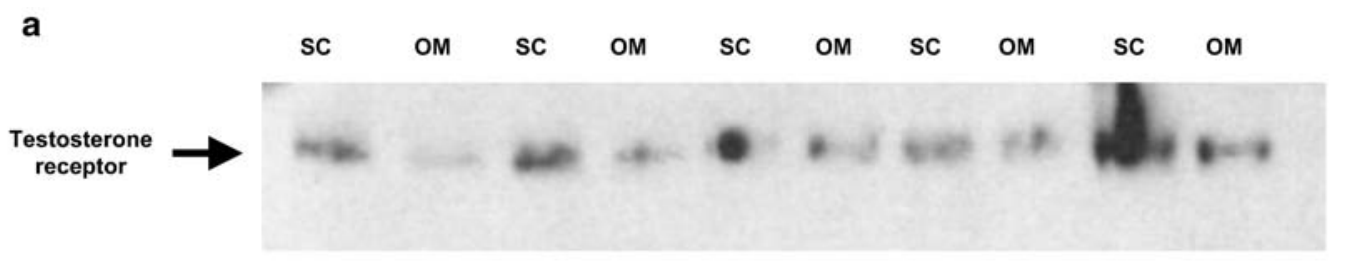

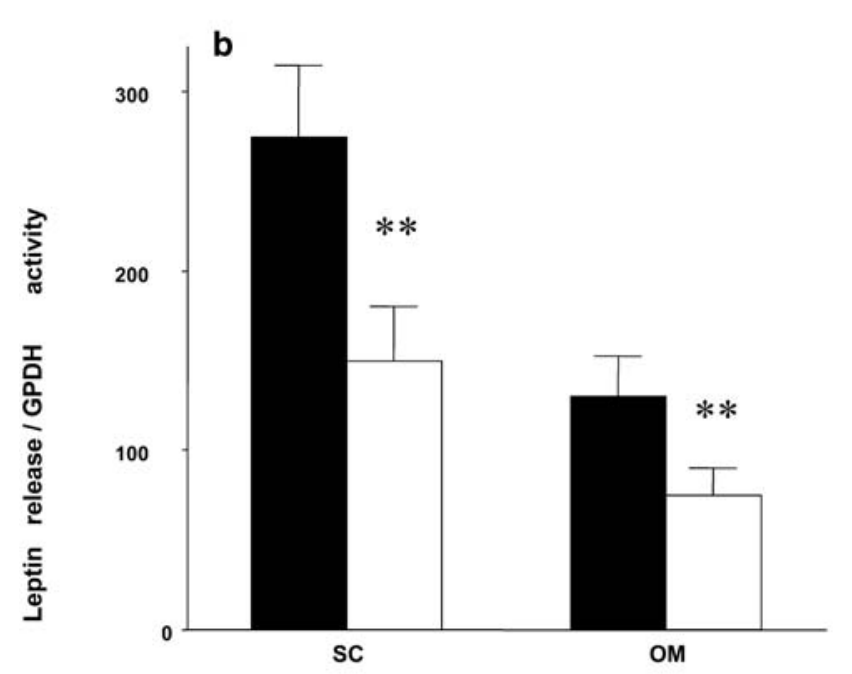

Fig. 7a-c. Specificity investigations of testosterone. Testosterone receptor expression (a) in omental and subcutaneous preadipocytes according to western blot. Leptin secretion (b) from subcutaneous or omental cells incubated with (open bars) or without (filled bars) $1 \mu \mathrm{mol} / 1$ testosterone $(n=25)$. Adrenalineinduced lipolysis (c) in subcutaneous or omental cells incubated with (open bars) or without (filled bars) $1 \mu \mathrm{mol} / \mathrm{l}$ of dihydrotestosterone $(n=8)$. ${ }^{*} p<0.05 ; * * p \leq 0.01$ See legend to Fig. 1 for further details. GPDH, glycerol-3-phosphate dehydrogenase; SC, subcutaneous; OM, omental

checked this material on the basis of BMI, with 13 subjects in one group (BMI $28-40 \mathrm{~kg} / \mathrm{m}^{2}$ ), and 13 subjects in a second group (BMI $41-72 \mathrm{~kg} / \mathrm{m}^{2}$ ). In each of the two subgroups testosterone was seen to affect lipolysis in subcutaneous cells but not in omental cells. A similar division was made on the basis of age for the results shown in Figs. 1 and 2. One subgroup had 13 subjects who were 22 to 36 years old, the other subgroup had 13 subjects who were 42 to 59 years old. The results in these two subgroups were also the same as in the whole group. When all experiments were considered together, we had data on seven men for adrenaline-induced lipolysis in subcutaneous differentiated pre-adipocytes. Basal lipolysis was $31 \pm 20$ without and $23 \pm 15$ with $1 \mu \mathrm{mol} / \mathrm{l}$ testosterone $(p=0.27)$. Adrenaline-induced lipolysis was $115 \pm 62$ without and $56 \pm 33$ with testosterone $(p=0.018)$.

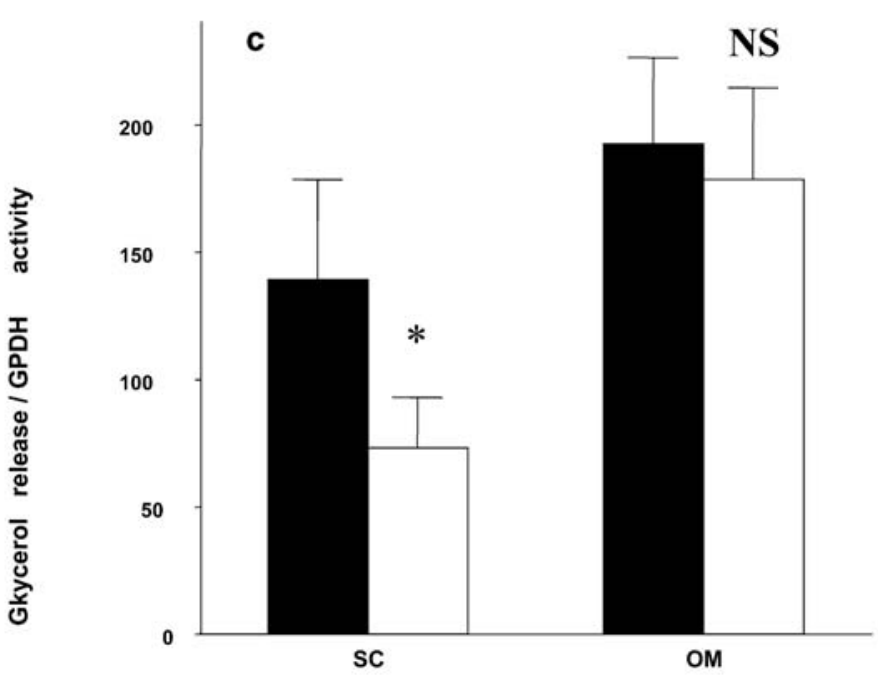

Discussion

Our findings on the importance of testosterone for regional differences in the regulation of visceral versus abdominal subcutaneous adipocyte lipolysis have clear implications for the pathophysiology of insulin resistance, bearing in mind the putative roles of sexand depot-specific effects on fatty acid mobilisation for the development of conditions characterised by insulin resistance $[6,7,8,9,10,19,20]$. Unfortunately, it is not possible to keep the cells in the culture system after full differentiation, so we were unable to study the testosterone effect after cells had fully matured. On the other hand, it is unlikely that the testosterone effect was related to the differentiation status of the pre-adipocytes, because an effect on lipolysis was seen as early as 3 days after hormone exposure. Our data clearly indicate a depot-specific effect of testosterone on lipolytic regulation. The hormone caused a concentration-dependent and marked decrease (50\% at maximum effective concentration) of adrenaline-stimulated lipolysis in differentiated preadipocytes from the abdominal subcutaneous but not from the omental fat depot. The effect was observed in moderately obese or morbidly obese subjects and was receptor-specific because it was, in part, reversed by the testosterone receptor blocker flutamide. It was not dependent on the age of the subject. The inhibitory effect of testosterone in subcutaneous cells was as marked in men as in women. Unfortunately, the experiments on omental cells of men were too few 
$(n=3)$ to allow conclusions about sex-specific effects in this region.

Our results for testosterone and lipolysis are different from those reported in several rodent studies. In rodents, testosterone up-regulates catecholamine-induced lipolysis when investigated in vivo or in vitro using mature fat cells or differentiated pre-adipocytes $[21,22,23]$. This difference between results for humans and for rodents suggests that there are important species differences in the effect of testosterone on lipolysis. Humans given testosterone have increased catecholamine-induced lipolysis in abdominal subcutaneous adipose tissue cultured in vitro [24]. However, this study was not placebo-controlled and it is possible that hormones given at high doses to living subjects have compensatory effects.

We have previously shown that lipolysis induced by noradrenaline is faster in differentiated preadipocytes from the omental than in similar preadipocytes from the abdominal subcutaneous adipose depot [15]. The same pattern was observed in this study using adrenaline. These findings, taken together with the depot-selective effects of testosterone on preadipocytes lipolysis, strongly suggest that the precursor cells for adipocytes in the subcutaneous and visceral region are different. This could be due to the existence of different mesenchymal stem cells in the two adipose areas or to some critical differences in early programming of a common precursor cell as a result of regional variations in the local environment of the relevant adipocytes. Regardless of the mechanisms, these findings could be important for the development of regional variation in lipolysis. In a putative model the relatively high circulating levels of testosterone observed in men and women with PCOS could cause selective inhibition of catecholamine-induced fatty acid mobilisation from the abdominal subcutaneous, but not from visceral adipose tissue. Moreover, a reduced ability of catecholamines to mobilise lipids from the abdominal subcutaneous region could lead to greater fat accumulation in this particular depot in people with upper-body obesity, which is an insulinresistant condition and more common among men than women, with the exception of PCOS.

Our data do not explain why fat accumulates in the visceral region. It is possible that enhanced lipid synthesis and not lipolytic activity is the major factor behind expansion of visceral adipose tissue. However, our findings could explain why in humans treated with testosterone the volume of visceral adipose tissue and triglyceride accumulation in this adipose region was selectively reduced $[25,26]$. A depot-specific inhibitory effect of testosterone on subcutaneous fat cell lipolysis would promote lipid mobilisation from visceral adipose tissue and a more pronounced loss of fat mass in this region.

Although most results were obtained with a high (1 $\mu \mathrm{mol} / \mathrm{l})$ concentration of testosterone, the results are probably still physiologically significant, as the half-maximal effective concentration was $10 \mathrm{nmol} / \mathrm{l}$. This is just above the normal range of circulating testosterone in women $(0.5-5.0 \mathrm{nmol} / \mathrm{l})$ and clearly within the normal range in men $(10-40 \mathrm{nmol} / \mathrm{l})$.

It has been observed with other incubation protocols that differentiated human pre-adipocytes and mature human cells from both regions express androgen receptors $[27,28]$. In theory some of the depot-specific effects of testosterone could be due to our use of a glitazone (i.e. rosiglitazone) during adipocyte differentiation, which could alter expression or signal transduction of testosterone receptors. This, though, is unlikely. Thus, we recently used this differentiation protocol to produce fat cells from human mesenchymal stem cells, which should be more sensitive to rosiglitazone than already committed pre-adipocytes. A similar lipolysis and protein secretory phenotype was observed in human fat cells derived from mesenchymal stem cells and pre-adipocytes [29]. Furthermore, our specificity tests provide strong evidence that the depot differences are not due to absence of testosterone receptors in omental cells or lack of function of these receptors. First, we were able to reproduce the lipolysis results with the very specific agonist dihydrotestosterone. Second, testosterone receptors were present in comparable amounts in both regions. Third, leptin secretion was inhibited by testosterone, confirming earlier data [30]. More importantly, however, we found that both omental and subcutaneous preadipocytes are sensitive to testosterone (leptin secretion $\approx 45 \%$ lower after hormone treatment). This suggests that testosterone receptors are functional in both depots, whereas the inhibitory signal to lipolysis is only present in subcutaneous cells. The site-specific effect of testosterone is probably not related to adipocyte differentiation, since the hormone had no effect on pre-adipocyte maturation as measured by GPDH activity, a finding which is consistent with previous results [31].

Catecholamine-induced lipolysis in human fat cells can be regulated at several levels in the lipolytic cascade [19]. Functional variations in the signalling through $\alpha_{2}$ - or $\beta$-adrenergic receptors, as well as alterations in the proteins forming the PKA-HSL complex or in the amount of perilipin, which coats the lipid droplets of adipocytes, could play a role $[19,32,33$, 34]. Although we cannot rule out that testosterone could affect $\alpha_{2}$-adrenoceptor signalling, the lipolysis data suggest that the important effect of the hormone is inhibition of $\beta$-adrenoceptor-mediated lipolysis. As testosterone caused a similar degree of inhibition, regardless of whether lipolysis was stimulated with adrenaline, adrenaline plus yohimbine, isoprenaline or dcAMP, the major inhibitory effect is probably downstream of cyclic AMP formation. No effect of testosterone on protein expression of the different subunits of PKA or on perilipin was observed. However, 
testosterone caused an almost 50\% reduction of the HSL protein in the subcutaneous region but was ineffective in this respect in the omental region. Thus testosterone-induced inhibition of expression of the HSL protein is an important factor in the hormone's ability to blunt catecholamine-induced lipolysis in subcutaneous adipocytes. Interestingly, previous results with dihydrotestosterone show inhibited protein expression of HSL in isolated mature human subcutaneous fat cells exposed to the hormone for $48 \mathrm{~h}$ [35]. At present, we do not know whether the effect of testosterone on HSL is due to transcriptional or translational regulation. The amount of cells available for such detailed studies was far too small.

An additional effect of testosterone in our study was the reduction of $\beta_{2}$-adrenoceptor protein. This appeared to be selective, as levels of $\beta_{1}$-adrenoceptors were unaltered. Unfortunately, we did not have enough protein for additional studies of other adrenoceptors, G-proteins or phosphodiesterases. However, the lipolysis data suggest that alterations in any additional proteins are of less importance for our findings with testosterone.

Because of lack of tissue, we had to pool adipocyte protein from different donors. It is unlikely that this procedure had an important bearing on findings, because identical amounts of total protein from each subject were pooled together and each control and each testosterone pool was composed of protein from the same donors. Moreover, the amount of specific protein detected by western blot procedures was proportional to the total amount of protein used in the assay and we corrected the protein values for a reference protein ( $\beta$-actin).

How do the present results relate to sex-specific differences in fat distribution or female sex hormones? At first one would expect men to have very little visceral fat as they have higher testosterone concentrations than women. However, sex-specific factors could still be involved in regional fat distribution, e.g. the more efficient lipid synthesis in visceral fat cells of men than women (not measured in this study), a factor which makes men more prone than women to accumulate visceral adipose tissue. Furthermore, the action of female sex hormones could have counteracting effects when compared with that of testosterone. In rodent fat cells, progesterone has specific lipogenic actions [36] and the opposite effects to testosterone on thermogenesis regulation, i.e. expression of uncoupling protein 1 in brown adipose tissue [37]. Finally, the situation in living humans could be somewhat different to the in vitro one of an experiment (long-term exposure to high concentrations of rosiglitazone during adipocyte differentiation). For example women, having in general low testosterone concentrations, could be more sensitive than men to an increase of the circulating hormone concentration (such as in PCOS) and thereby be more sensitive than men to the effects of testosterone on subcutaneous adipocyte lipolysis.

In summary, this study shows that testosterone in physiological concentrations inhibits catecholamineinduced lipolysis in differentiated pre-adipocytes from the subcutaneous but not from the visceral fat depot. This could be due to a depot-specific inhibition of the protein expression of HSL by testosterone in subcutaneous adipocytes (and to some extent also to a decrease in the amount of $\beta_{2}$-ARs), and could also be an important pathophysiological factor behind the insulin-resistant phenotype both of upper-body obesity (which is common in men), and of hyperandrogenic PCOS.

Acknowledgements. This study was supported by grants from Åke Wiberg Foundation, Tore Nilsson Foundation, Swedish Medical Society, Foundation for Scientific Work in Diabetes, Swedish Research Council, Swedish Heart and Lung Association, Swedish Diabetes Association, and Novo Nordic Fund. The excellent technical assistance of G. Åström is greatly appreciated. We thank C. Holm of Lund University, Sweden for the HSL antibody.

\section{References}

1. Bergman RN, Citters GW van, Mittelman SD et al. (2001) Central role of the adipocyte in the metabolic syndrome. J Investig Med 49:119-126

2. Zacur HA (2001) Polycystic ovary syndrome, hyperandrogenism and insulin resistance. Obstet Gynecol Clin North Am 28:21-33

3. Chaldakov GN, Stankulov IS, Hristova M, Ghenev PI (2003) Adipobiology of disease: adipokines and adipokinetargeted pharmacology. Curr Pharm Des 9:1023-1031

4. Cederberg A, Enerback S (2003) Insulin resistance and type 2 diabetes-an adipocentric view. Curr Mol Med 3: $107-125$

5. Arner P (2003) The adipocyte in insulin resistance: key molecules and the impact of the thiazolidinediones. Trends Endocrinol Metab14:137-145

6. Arner $\mathrm{P}(1998)$ Not all fat is alike. Lancet 351:1301-1302

7. Montague CT, O'Rahilly S (2000) The perils of portliness: causes and consequences of visceral adipocytes. Diabetes 49:883-888

8. Wajchenberg BL (2000) Subcutaneous and visceral adipose tissue: their relation to the metabolic syndrom. Endocr Rev 21:697-738

9. Gasteyger C, Tremblay A (2002) Metabolic impact of body fat distribution. J Endocrinol Invest 25:876-883

10. Bosello O, Zamboni M (2000) Visceral obesity and metabolic syndrome. Obes Rev 1:47-56

11. Lonnqvist F, Thorne A, Large V, Arner P (1997) Sex differences in visceral fat lipolysis and metabolic complications of obesity. Arterioscler Thromb Vasc Biol 17:1472-1480

12. Lofgren P, Hoffstedt J, Ryden M et al. (2002) Major gender differences in the lipolytic capacity of abdominal subcutaneous fat cells in obesity observed before and after long-term weight reduction. J Clin Endocrinol Metab 87:764-771

13. Ek I, Arner P, Bergqvist A, Carlstrom K, Wahrenberg H (1997) Impaired adipocyte lipolysis in nonobese women with the polycystic ovary syndrome: a possible link to insulin resistance? J Clin Endocrinol Metab 82:1147-1153 
14. Ek I, Arner P, Ryden M et al. (2002) A unique defect in the regulation of visceral fat cell lipolysis in the polycystic ovary syndrome as an early link to insulin resistance. Diabetes 51:484-492

15. Harmelen V van, Dicker A, Ryden M et al. (2002) Increased lipolysis and decreased leptin production by human omental as compared with subcutaneous preadipocytes. Diabetes 51:2029-2036

16. Hauner H, Entenmann G, Wabitsch M et al. (1989) Promoting effect of glucocorticoids on the differentiation of human adipocyte precursor cells cultured in a chemically defined medium. J Clin Invest 84:1663-1670

17. Hellmer J, Arner P, Lundin A (1989) Automatic luminometric kinetic assay of glycerol for lipolysis studies. Anal Biochem 177:132-137

18. Large V, Arner P, Reynisdottir S et al. (1998) Hormonesensitive lipase expression and activity in relation to lipolysis in human fat cells. J Lipid Res 39:1688-1695

19. Lafontan M, Barbe P, Galitzky J et al. (1997) Adrenergic regulation of adipocyte metabolism. Hum Reprod 1:6-20

20. Blaak E (2001) Gender differences in fat metabolism. Curr Opin Clin Nutr Metab Care 4:499-502

21. Xu XF, De Pergola G, Bjorntorp P(1990) The effects of androgens on the regulation of lipolysis in adipose precursor cells. Endocrinology 126:1229-1234

22. De Pergola G, Holmang A, Svedberg J, Giorgino R, Bjorntorp P (1990) Testosterone treatment of ovariectomized rats: effects on lipolysis regulation in adipocytes. Acta Endocrinol 123:61-66

23. Xu XF, De Pergola G, Bjorntorp P (1991) Testosterone increases lipolysis and the number of beta-adrenoceptors in male rat adipocytes. Endocrinology 128:379-382

24. Rebuffe-Scrive M, Marin P, Bjorntorp P (1991) Effect of testosterone on abdominal adipose tissue in men. Int $\mathrm{J}$ Obes 15:791-795

25. Marin P, Holmang S, Jonsson L et al. (1992) The effects of testosterone treatment on body composition and metabolism in middle-aged obese men. Int J Obes Relat Metab Disord 16:991-997

26. Marin P, Lonn L, Andersson B et al. (1996) Assimilation of triglycerides in subcutaneous and intraabdominal adipose tissue in vivo in men: effects of testosterone. J Clin Endocrinol Metab 81:1018-1022
27. Dieudonne MN, Pecquery R, Boumediene A, Leneveu MC, Giudicelli Y (1998) Androgen receptors in human preadipocytes and adipocytes: regional specificities and regulation by sex steroids. Am J Physiol 274:C1645-C1652

28. Joyner J, Hutley L, Cameron D (2002) Intrinsic regional differences in androgen receptors and dihydrotestosterone metabolism in human preadipocytes. Horm Metab Res 34: 223-228

29. Ryden M, Dicker A, Gotherstrom C et al. (2003) Functional characterization of human mesenchymal stem cell-derived adipocytes. Biochem Biophys Res Commun 311:391-397

30. Wabitsch M, Blum WF, Muche R et al. (1997) Contribution of androgens to the gender difference in leptin production in obese children and adolescents. J Clin Invest 100: 808-813

31. Anderson LA, McTernan PG, Barnett AH, Kumar S (2001) The effects of androgens and estrogens on preadipocyte proliferation in human adipose tissue: influence of gender and site. J Clin Endocrinol Metab 86:5045-5051

32. Londos C, Brasaemle DL, Schultz CJ, Segrest JP, Kimmel AR (1999) Perilipins, ADRP, and other proteins that associate with intracellular neutral lipid droplets in animal cells. Semin Cell Dev Biol 10:51-58

33. McKnight GS, Cummings DE, Amieux PS et al. (1998) Cyclic AMP, PKA, and the physiological regulation of adiposity. Recent Prog Horm Res 53:139-159

34. Holm C, Osterlund T, Laurell H, Contreras JA (2000) Molecular mechanisms regulating hormone-sensitive lipase and lipolysis. Annu Rev Nutr 20:365-393

35. Anderson LA, McTernan PG, Harte AL, Barnett AH, Kumar S (2002)The regulation of HSL and LPL expression by DHT and flutamide in human subcutaneous adipose tissue. Diabetes Obes Metab 4:209-213

36. Lacasa D, Le Liepvre X, Ferre P, Dugail I (2001) Progesterone stimulates adipocyte determination and differentiation $1 /$ sterol regulatory element-binding protein $1 \mathrm{c}$ gene expression. Potential mechanism for the lipogenic effect of progesterone in adipose tissue. J Biol Chem 276:1151211516

37. Rodriguez AM, Monjo M, Roca P, Palou A (2002) Opposite actions of testosterone and progesterone on UCP1 mRNA expression in cultured brown adipocytes. Cell Mol Life Sci 59:1714-1723 